\title{
PENGGUNAAN PELEPAH KELAPA SAWIT FERMENTASI DENGAN BERBAGAI LEVEL BIOMOL+ PADA PAKAN TERHADAP KECERNAAN DOMBA LOKAL JANTAN
}

\author{
(Use of Oil Palm sheaths Fermentation with Various Levels Biomol + on feed digestibility \\ on Weaning Local Ram)
}

\author{
Sari Putri ${ }^{1}$, Armyn Hakim Daulay ${ }^{2}$ dan Usman Budi² \\ 1. Mahasiswa Program Studi Peternakan Fakultas Pertanian Universitas SumateraUtara \\ 2. Staf Pengajar Program Studi Peternakan Fakultas Pertanian Universitas Sumatera Utara
}

\begin{abstract}
This study aims to determine the effect of fermented oil palm frond with various levels Biomol+ on the dry matter and organic matter digestibility on sheep. The experiment was conducted at the Faculty of Agriculture, University of Sumatra Utara in December 2013 to February 2014. Experiment design used completely randomized design (CRD) with 4 treatments and 4 replications. The treatments consists of $P 0$ : (without Biomol+); P1: (Biomol+ $5 \%) ;$ P2:(Biomol+ $10 \%) ;$ P3 : (Biomol+15\%). The results showed that fermented oil palm frond with Biomol+ $15 \%$ gave significantly different compared with oil palm frond without fermentation in improving dry matter and organic matter digertibility. The digestibility was haighest in P3 (fermented palm frond with Biomol $+15 \%$ ) and the lowest digestibility contained in P0 (fermented palm frond without Biomol+). The conclusion of this study is increasing the levels of Biomol+ increased the level of dry matter and organic matter digestibility.
\end{abstract}

Keywords : Oil Palm Frond, Fermentation, Biomol+, Digestibility, Local Lamb.

\begin{abstract}
ABSTRAK
Penelitian ini bertujuan untuk mengetahui pengaruh penggunaan pelepah kelapa sawit fermentasi dengan berbagai level biomol+ pada pakan terhadap kecernaan bahan kering dan bahan organik. Penelitian dilaksanakan di Fakultas Pertanian Univesitas Sumatera Utara pada bulan Desember 2013 sampai dengan Februari 2014. Rancangan yang digunakan dalam penelitaian ini adalah rancangan acak lengkap (RAL) dengan 4 perlakuan. Perlakuan ini terdiri atas P0 (tanpa biomol+); P1 (biomol+ 5\%); P2 (biomol+ 10\%); P3 (biomol+ $15 \%)$. Hasil penelitian menunjukan menunjukkan fermentasi pelepah kelapa sawit dengan Biomol+ $15 \%$ memberikan pengaruh yang nyata dibandingkan pelepah kelapa sawit tanpa fermentasi terhadap kecernaan. Rataan kecernaan tertinggi terdapat pada P3 (fermentasi pelepah kelapa sawit Biomol+ 15\%) dan rataan kecernaan terndah terdapat pada P0 (fermentasi pelepah kelapa sawit tanpa Biomol+). Kesimpulan penelitian ini adalah semakin tinggi level pemberian biomol+ semakin tinggi pula tingkat kecernaan bahan kering dan kecernaan bahan organik.
\end{abstract}

Kata kunci : Pelepah kelapa sawit, Fermentasi, Biomol+, Kecernaan, Domba lokal. 


\section{PENDAHULUAN}

Pakan merupakan salah satu faktor utama yang mempengaruhi sukses tidaknya usaha peternakan domba. Salah satu upaya dalam pengadaan pakan bagi ternak adalah memanfaatkan seoptimal mungkin lahan serta pemanfaatan limbah dan hasil samping komoditi pertanian. Hal ini tidak terlepas dari semakin sulitnya memperoleh hijauan pakan ternak karena semakin banyaknya usaha peternakan berdiri.

Ciri-ciri domba lokal adalah tubuhnya kecil, warnanya bermacam-macam. Kadangkadang terdapat lebih dari satu warna pada ekor hewan. Domba jantan bertanduk kecil, sedangkan domba betina tidak bertanduk. Berat domba jantan berkisar 30-40 kg, yang betina berkisar $15-20 \mathrm{~kg}$.

Untuk keberhasilan pengembangan domba merupakan salah satu komponen esensial harus terjamin kuantitas dan kualitasnya. Mengingat bahwa ketersediaan lahan semakin sempit, baik sebagai tempat berusaha maupun sebagai sumber pakan semakin terbatas, maka pemanfaatan sumber daya alternatif untuk menjamin kelanjutan serta efisiensi usaha ternak domba merupakan tuntutan mendesak yang perlu di tangani.

Perkebunan kelapa sawit sampai saat ini terus berkembang hampir di semua propinsi di Indonesia sehingga luasannya terus meningkat. Luas perkebunan kelapa sawit di Indonesia 6.700.000 ha. Propinsi Sumatera Utara memiliki perkebunan kelapa sawit yang paling luas dibanding dengan propinsi lain yang ada di Indonesia, yaitu 1.675.000 ha (25\%). Salah satu produk limbah padat perkebunan kelapa sawit yang belum banyak dimanfaatkan sebagai pakan ternak adalah pelepah kelapa sawit (BPS, 2008).

Produksi kelapa sawit ini terkonsentrasi pada satu kawasan dalam jumlah yang berlimpah dan tersedia sepanjang tahun sehingga memiliki peluang yang besar sebagai pemasok bahan baku pakan. Pada saat panen tandan buah segar, 1 - 2 helai pelepah kelapa sawit dipotong dengan tujuan memperlancar penyerbukan dan mempermudah panen berikutnya. Jumlah pelepah kelapa sawit yang telah berproduksi dapat mencapai 40 - 50 pelepah/pohon/tahun dengan bobot pelepah sebesar 4,5 $\mathrm{kg}$ berat kering per pelepah (Sutardi, 1996).

Pelepah kelapa sawit adalah salah satu komoditas pertanian yang paling potensial dan terdapat hampir diseluruh daerah di Indonesia. Potensial limbah daun pelepah sawit untuk bahan baku pakan cukup melimpah dan belum dimanfaatkan secara optimal. Pelepahkelapa sawit termasuk kategori limbah basah karena masih mengandung kadar air sekitar 75\%, sehingga dapat rusak dengan cepat apabila tidak segera diproses (Purba et al. ,1997). 
Teknologi silase adalah suatu proses fermentasi mikroba merubah pakan menjadi meningkat kandungan nutrisinya dan disukai ternak karena rasanya relatif manis. Silase merupakan proses mempertahankan kesegaran bahan pakan dengan kandungan bahan kering $30-35 \%$ (Sapienza et al., 1993).

Kecernaan pakan adalah bagian pakan yang tidak dieksresikan dalam feses dan selanjutnya dapat diasumsikan sebagai bagian yang diserap oleh ternak. Selisih antara nutrien yang dikandung dalam bahan makanan dengan nutrien yang ada dalam feses merupakan bagian nutrien yang dicerna (McDonald et al., 1995). Biasanya dinyatakan dalam dasar bahan kering dan apabila dinyatakan dalam persentase maka disebut koofisien cerna (Tillman et al., 1998).

Kecernaan pakan didefinisikan sebagai bagian yang tidak dieksresikan dalam feses dan diasumsikan diserap oleh ternak (McDonald et al., 1995). Biasanya dinyatakan dalam dasar bahan kering dan apabila dinyatakan dalam persentase maka disebut koefisien cerna (Tillman et al., 1998). Koefisien cerna merupakan selisih antara nutrien yang terkandung dalam pakan yang dikonsumsi dengan nutrien yang terkandung dalam feses, sedangkan nutrien yang terkandung dalam feses adalah jumlah yang tertinggal dalam tubuh hewan atau jumlah dari nutrien yang dapat dicerna (Anggorodi, 1994).

Atas dasar pemikiran inilah perlu diadakan suatu penelitian tentang pemanfaatan pelepah daun kelapa sawit yang difermentasi dengan biomol sebagai pakan ternak yang diharapkan dapat meningkatkan kecernaan pada domba jantan lokal.

\section{BAHAN DAN METODE PENELITIAN}

\section{Tempat dan Waktu Penelitian}

Penelitian ini dilaksanakan di Laboratorium Biologi Peternakan Fakultas Pertanian Universitas Sumatera Utara J1. Prof. A. Sofyan No. 3 Medan. Penelitian ini berlangsung selama tiga bulan, di mulai bulan Desember sampai dengan Maret 2013.

\section{Bahan dan Alat Penelitian}

Bahan yang digunakan antara lain: Domba Lokal Jantan lepas sapih sejumlah 20 ekor dengan kisaran bobot badan awal rata-rata 10-13 kg, cincangan pelepah kelapa sawit, bungkil inti sawit, ampas tahu, dedak halus, molases, ultra mineral, garam, ragi roti, obat-obatan seperti obat cacing (Kalbazen), anti bloat untuk obat kembung, terramycin (salep mata) dan vitamin, air minum. 
Alat yang digunakan antara lain : Kandang individu 20 unit beserta perlengkapannya, tempat pakan dan minum, timbangan bobot hidup dan bobot karkas berkapasitas $50 \mathrm{~kg}$ dengan kepekaan $50 \mathrm{~g}$, timbangan berkapasitas $2 \mathrm{~kg}$ dengan kepekaan $10 \mathrm{~g}$ untuk menimbang pakan, ember, sapu, goni plastik, sapu, alat tulis, alat penerangan.

\section{Metode Penelitian}

Menggunakan rancangan acak lengkap dengan menggunakan 4 perlakuan 5 ulangan. Adapun perlakuan tersebut adalah :

Po : Fermentasi Pelepah Kelapa Sawit tanpa Biomol (Kontrol) + pakan basal

P1 : Fermentasi Pelepah Kelapa Sawit dengan Biomol sebanyak $5 \%$ + pakan basal

P2 : Fermentasi Pelepah Kelapa Sawit dengan Biomol sebanyak $10 \%$ + pakan basal

P3 : Fermentasi Pelepah Kelapa Sawit dengan Biomol sebanyak $15 \%+$ pakan basal

Ket : Perlakuan (P0, P1, P2 dan P3), Ulangan (U1, U2, U3, U4, dan U5). Model rancangan acak lengkap yang digunakan adalah :

$$
\mathrm{Y}_{\mathrm{ij}}=\mu+\quad \varepsilon
$$

Keterangan :

$\mathrm{Y}_{\mathrm{ij}}=$ Hasil Pengamatan pada ulangan ke-i dan perlakuan ke-j

$\mu=$ Nilai rata-rata (mean) harapan

$=$ Pengaruh faktor perlakuan

$\varepsilon=$ Pengaruh galat (experimental error)

\section{Parameter Penelitian}

\section{Kecernaan Bahan Kering (KcBK)}

Kecernaan bahan kering didapatkan dengan cara mengurangi bahan kering konsumsi dengan bahan kering feses lalu dibagi dengan bahan kering konsumsi yang kemudian dikali seratus persen. Bahan kering konsumsi didasarkan.

$$
\mathrm{KcBK}=(\underline{\text { Konsumsi BK }- \text { Pengeluaran BK}}) \times 100 \%
$$

Konsumsi BK

\section{Kecernaan Bahan Organik (KcBO)}

Kecernaan bahan organik didapatkan dengan cara mengurangi bahan organik konsumsi dengan bahan organik feses lalu dibagi dengan bahan organik konsumsi yang kemudian dikali seratus persen.

$$
\mathrm{KcBO}=(\underline{\text { Konsumsi BO }- \text { Pengeluaran BO }}) \times 100 \%
$$

Konsumsi BO 
Tabel 1. Formulasi pakan selama penelitian (\%):

\begin{tabular}{|c|c|c|c|c|}
\hline Bahan pakan & $\mathrm{P}_{0}$ & $\mathrm{P}_{1}$ & $\mathrm{P}_{2}$ & $\mathrm{P}_{3}$ \\
\hline Pelepah Sawit & 50 & 50 & 50 & 50 \\
\hline Bungkil inti sawit & 30 & 30 & 30 & 30 \\
\hline \multicolumn{5}{|l|}{ Fermentase Pelepah Sawit } \\
\hline P0 : Tanpa Biomol & 5 & - & - & - \\
\hline P1 : Biomol $5 \%$ & - & 5 & - & - \\
\hline P2 : Biomol $10 \%$ & - & - & 5 & - \\
\hline P3 : Biomol $15 \%$ & - & - & - & 5 \\
\hline Dedak padi & 8 & 8 & 8 & 8 \\
\hline Ampas tahu & 4 & 4 & 4 & 4 \\
\hline Molases & 2 & 2 & 2 & 2 \\
\hline Ultra mineral & 0,5 & 0,5 & 0,5 & 0,5 \\
\hline Garam & 0,5 & 0,5 & 0,5 & 0,5 \\
\hline Jumlah & 100 & 100 & 100 & 100 \\
\hline \multicolumn{5}{|c|}{ Kandungan Nutrisi } \\
\hline PK $(\%)$ & 12,64 & 12,70 & 12,78 & 12,84 \\
\hline SK $(\%)$ & 22,85 & 23,27 & 23,22 & 23,84 \\
\hline LK (\%) & 5,23 & 5,24 & 5,25 & 5,28 \\
\hline TDN (\%) & 68,33 & 68,33 & 68,50 & 68,60 \\
\hline
\end{tabular}

\section{HASIL DAN PEMBAHASAN}

Rataan dari parameter yaitu : konsumsi bahan kering, konsumsi bahan organik, kecernaan bahan kering dan kecernaan bahan organik hasil penelitian dapat dilihat pada Tabel 2.

Tabel 2. Rekapitulasi hasil penelitian

\begin{tabular}{lllll}
\hline Perlakuan & $\begin{array}{l}\text { Konsumsi BK } \\
(\mathrm{g} / \text { ekor/hari })\end{array}$ & $\begin{array}{l}\text { Konsumsi BO } \\
(\mathrm{g} / \text { ekor/hari })\end{array}$ & $\begin{array}{l}\text { Kecernaan BK } \\
(\%)\end{array}$ & $\begin{array}{l}\text { Kecernaan BO } \\
(\%)\end{array}$ \\
\hline P0 & $464.42^{\mathrm{b}} \pm 5.82$ & $419.03^{\mathrm{c}} \pm 209.55$ & $56.41^{\mathrm{c}} \pm 1.00$ & $59.94^{\mathrm{d}} \pm 0.78$ \\
P1 & $461.80^{\mathrm{c}} \pm 12.59$ & $419.21^{\mathrm{c}} \pm 209.81$ & $56.48^{\mathrm{c}} \pm 0.43$ & $60.29^{\mathrm{c}} \pm 0.30$ \\
P2 & $459.66^{\mathrm{c}} \pm 1.78$ & $420.52^{\mathrm{b}} \pm 210.26$ & $57.56^{\mathrm{b}} \pm 0.14$ & $61.38^{\mathrm{b}} \pm 0.12$ \\
P3 & $469.33^{\mathrm{a}} \pm 5.53$ & $434.45^{\mathrm{a}} \pm 217.27$ & $58.44^{\mathrm{a}} \pm 0.30$ & $62.12^{\mathrm{a}} \pm 0.27$ \\
\hline Total & 1855.21 & 1693.21 & 228.89 & 243.73 \\
\hline Rataan & 463.8025 & 423.3025 & 57.2225 & 60.9325 \\
\hline
\end{tabular}

Ket : $\quad$ superskrip dengan huruf kecil yang berbeda kearah kolom menunjukkan pengaruh nyata $(\mathrm{P}<0,05)$

Tabel rekapitulasi menunjukkan bahwa pelepah kelapa sawit fermentasi dengan berbagai biomol+ terhadap kecernaan bahan kering dan bahan organik pada domba jantan lokal memberika pengaruh yang sangat nyata terhadap konsumsi bahan kering, konsumsi bahan organik, kecernaan bahan kering, dan kecernaan bahan organik. Pada konsumsi bahan kering perlakuan P3 berpengruh nyata dibandingkan dengan perlakuan P0, P1, P2 serta 
perlakuan P2 menunjukkan pengaruh nyata terhadap P1. Pada konsumsi bahan organik perlakuan P3 berpengaruh nyata dibandingkan dengan perlakuan P0, P1, P2. Pada kecernaan bahan kering perlakuan P3 berpengaruh nyata dibandingkan perlakuan P0, P1, P2. Pada kecernaan bahan organik perlakuan P3 berpengaruh nyata dibandingkan dengan perlakuan $\mathrm{P} 0, \mathrm{P} 1, \mathrm{P} 2$.

\section{Konsumsi Bahan Kering}

Konsumsi bahan kering domba lokal jantan dihitung dari total konsumsi pakan komplit pelepah kelapa sawit fermentasi dengan berbagai lever biomol+ yang diberikan dan dihitung berdasarkan kandungan bahan keringnya. Pengambilan data konsumsi bahan kering diambil selama 7 hari terakhir dari masa pemeliharaan domba lokal jantan. Berdasarkan tabel rekapitulasi dapat dilihat rataan konsumsi bahan kering domba sebesar 463.805 g/ekor/hari. Rataan konsumsi bahan kering terdapat pada perlakuan P3 (biomol+ 15\%) sebesar 469.33 g/ekor/hari, sedangkan rataan konsumsi pakan terendah terdapat pada perlakuan P2 (biomol+ 10\%) sebesar 459.66 g/ekor/hari. Pendapat Lubis (1993) yang menyatakan bahwa konsumsi bahan kering dipengaruhi beberapa hal diantaranya : 1) faktor pakan, meliputi daya cerna dan palatabilitas dan 2) factor ternak yang meliputi bangsa, jenis kelamin, umur dan kondisi kesehatan ternak. Hal ini juga sesuai dengan pendapat Parakkasi (1995) yang juga menyatakan bahwa palatabilitas pakan merupakan salah satu faktor yang memepengaruhi jumlah mikroba rumen sehingga pakan yang memiliki nilai kecernaan yang lebih baik.

\section{Konsumsi Bahan Organik}

Perhitungan konsumsi bahan organik pada pakan domba lokal jantan dihitung dari total konsumsi hijauan dan pakan komplit pelepah kelapa sawit fermentasi yang diberikan dan dihitung berdasarkan kandungan bahan organiknya. Data konsumsi bahan organik selama 7 hari dapat dilihat pada Tabel rekapitulasi. Berdasarkan Tabel tersebut dapat dilihat rataan konsumsi bahan organik pakan domba jantan lokal sebesar 423.30 g/ekor/hari. Rataan konsumsi bahan organik pakan pada domba jantan lokal tertinggi diperoleh pada perlakuan P3 (biomol+ 15\%) sebesar 434.45 g/ekor/hari dan konsumsi bahan organik terendah diperoleh pada perlakuan P0 (tanpa biomol) sebesar 419.03 g/ekor/hari.

Jumlah konsumsi bahan kering akan berpengaruh terhadap konsumsi bahan organik, semakin meningkat konsumsi bahan kering makan konsumsi bahan organik juga makin meningkat dan sebaliknya (Kamal, 1994). Konsumsi bahan organik berkorelasi positif 
dengan konsumsi bahan kering, hal ini disebabkan karna zat-zat yang terkandung dalam bahan organik terdapat pula bahan kering. Menurut Tillman et all., (1998), bahan kering terdiri dari bahan organik dan anorganik, didalam bahan organik itu sendiri terkandung lemak kasar, protein kasar, serat kasar, dan BETN, sedangkan bahan anorganik terdiri dari abu.

\section{Kecernaan Bahan Kering}

Kecernaan merupakan bagian dari pakan yang tidak diekskresikan dalam feses (Tillman et all, 1998). Kecernaan pakan dapat digunakan sebagai petunjuk tentang kecernaan rendah menunjukkan bahwa pakan tersebut kurang mampu menyuplai nutrien untuk hidup pokok maupun untuk tujuan produksi ternak. Kecernaan bahan kering didapatkan dengan cara mengurangi bahan kering konsumsi dengan bahan kering feses lalu dibagi dengan bahan kering konsumsi yang kemudian dikali seratus persen. Data kecernaan bahan kering dapat dilihat pada Gambar 1.

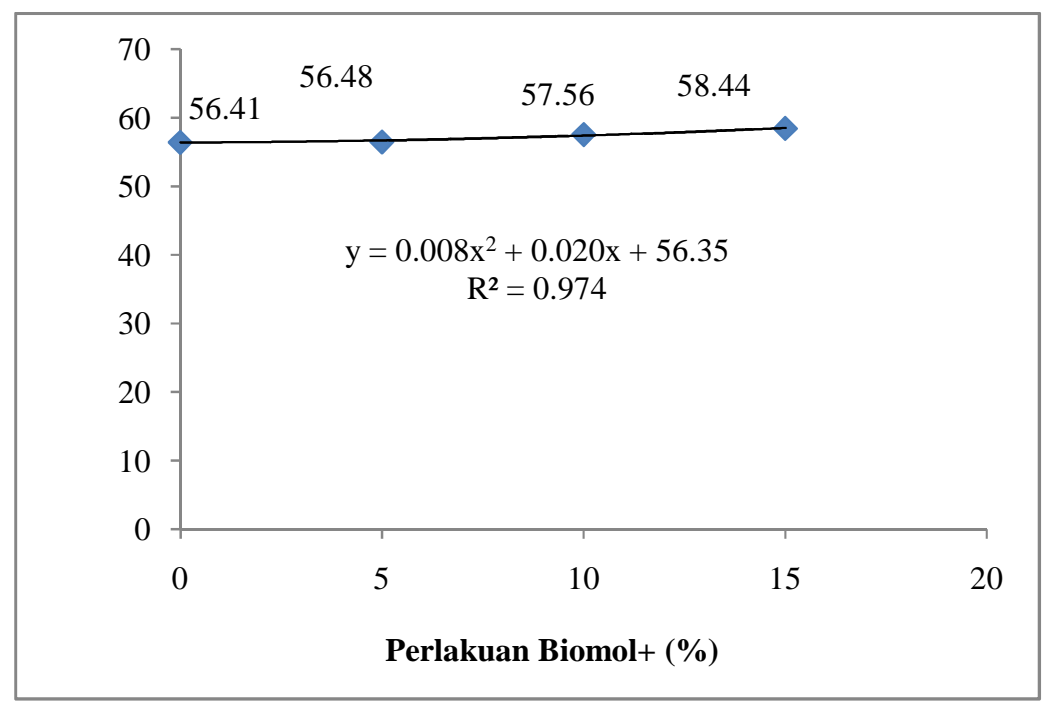

Gambar 1. Rataan Kecernaan Bahan Kering

Gambar 1 menunjukkan bahwa kecernaan bahan kering pada perlakuan P0 tanpa biomol+ berpengaruh sangat nyata lebih rendah $(\mathrm{P}<0.01)$ terhadap kecernaan bahan kering dan perlakuan P3 nyata lebih tinggi. Hasil uji lanjut orthogonal polynomial menunjukkan bahwa perlakuan memberikan respon kuadrater terhadap kecernaan bahan kering dengan persamaan $Y=0,008 x^{2}+0,020 x-56,35$ dengan koefisien determinasi $\left(R^{2}\right) 0.974$. Hal ini membuktikan bahwa semakin tinggi level bioaktifator tersebut diberikan maka, akan menghasilkan enzim yang lebih banyak, sehingga daya cerna akan lebih tinggi. Hasil 
penelitian menggambarkan bahwa pelepah kelapa sawit yang difermentasi dengan Biomol+ $15 \%$ secara umum lebaih baik dibandingkan dengan pakan pelepah kelapa sawit fermentasi dengan 10\%, 5\% atau bahkan tanpa menggunakan biomol+. Keterangan dari Sony (2012) menyatakan bahwa probiotik Biomol+ dapat membantu proses pemecahan polisakarida pakan ruminansia yaitu komponen selulosa dan hemiselulosa sehingga dapat difermentasikan oleh mikroba rumen lebih efektif untuk pembentukan asam lemak mudah terbang dan massa mikroba rumen menjadi sumber protein. Keseimbangan energi dan protein yang dapat dimanfaatkan didalam saluran cerna pasca rumen harus diupayakan agar pemanfaatan nutrisi sempurna.

\section{Kecernaan Bahan Organik}

Kecernaan bahan organik pakan pada domba jantan lokal dihitung dari selisih konsumsi bahan organik pakan pada domba yang dikurangi dengan feses domba (dalam bahan organik) yang dikeluarkan dibandingakan dengan konsumsi bahan organik domba. Dan kecernaan bahan organik domba dapat dilihat pada gambar 2. Menurut Sutardi (1980), nilai kecernaan bahan organik dari suatu pakan dapat menentukan kualitas pakan tersebut. Berdasarkan Tabel 13. dapat dilihat rataan kecernaan bahan organik feses domba jantan lokal sebesar 60,93\%. Rataaan kecernaan bahan organik feses pada domba jantan lokal tertinggi diperoleh dari perlakuan P3 sebesar 62,12\% dan kecernaan bahan kering feses terendah diperoleh dari perlakuan P0 sebesar 59,94\%.

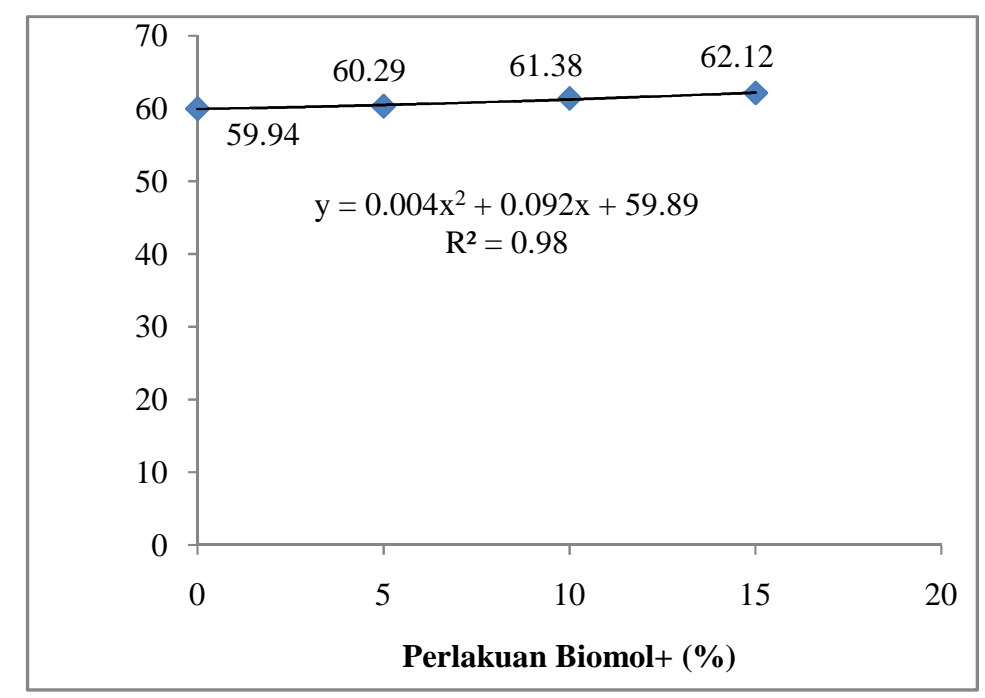

Gambar 2. Rataan kecernaan bahan organik 
Hal yang mempengaruhi tersebut yaitu dengan penggunaan probiotik Biomol+ yang memiliki campuran berbagai mikroorganisme yang bermanfaat dalam pemecahan serat, protein dan lemak pakan sehingga akan mendorong proses fermentasi pakan serta meningkatkan sintesis protein mikroba rumen (Sony, 2012).

Grafik 2 menunjukkan bahwa kecernaan bahan organik pada perlakuan $\mathrm{P}_{0}$ tanpa biomol+ berpengaruh sangat nyata lebih rendah $(\mathrm{P}<0.01)$ terhadap kecernaan bahan organik dan perlakuan P3 nyata lebih tinggi. Hasil uji lanjut orthogonal polynomial menunjukkan bahwa perlakuan memberikan respon kuadrater terhadap kecernaan bahan kering dengan persamaan $\mathrm{Y}=0,004 \mathrm{x}^{2}+0,092 \mathrm{x}-59,89$ dengan koefisien determinasi $\left(\mathrm{R}^{2}\right)$ 0.98. Sesuai dengan pernyataan Suwandyastuti (1991) menerangkan bahwa bahan pakan yang mempunyai kandungan nutrien yang sama memungkinkan kecernaan bahan organiknya mengikuti kecernaan bahan keringnya, tetapi sering terjadi perbedaan. Hasil penelitian menggambarkan bahwa pelepah kelapa sawit yang difermentasi dengan biomol+ $15 \%$ secara umum lebaih baik dibandingkan dengan pakan pelepah kelapa sawit fermentasi dengan 10\%, 5\% atau bahkan tanpa menggunakan biomol+.

\section{KESIMPULAN}

Pemberian pelepah kelapa sawit fermentasi dengan berbagai level biomol+ dapat meningkatkan kecernaan sesuai dengan pemberian level biomol+, semakin tinggi level pemberian biomol+ (15\%) semakin tinggi pula tingkat kecernaan bahan kering dan kecernaan bahan organik. Disarankan pelepah kelapa sawit fermentasi dengan berbagai biomol+ dapat diolah menjadi pakan ternak ruminansia dikarenakan dapat mengimbangi hijauan sehingga pemanfaatan pelepah kelapa sawit dapat dimanfaatkan secara optimal sebagai integrasi perkebunan dengan peternakan.

\section{DAFTAR PUSTAKA}

Anggorodi, R. 1994. Ilmu Makanan Ternak Umum. Gramedia. Jakarta.

Badan Pusat Statistik. 2008. Statistik Indonesia. BPS Jakarta -Indonesia2008.

Kamal, M., 1994. Nutrisi Ternak 1. Laboratorium Makanan Ternak Jurusan Nutrisi dan Makanan Ternak. Fakultas Peternakan. Universitas Gadjah Mada, Yogyakarta.

Lubis, D. A. 1993. Ilmu Makanan Ternak, Pembangunan, Jakarta.

McDonald, P., R. A. Edwards and J. F. D. Greenhalgh. 1995. AnimalNutricion. Fourth Edition.Copublished in The United States With John Wiley And Sons, Inc. New York. 
Parakkasi, A. 1995. Ilmu Nutrisi Pakan Ternak Ruminansia. UI Press. Jakarta.

Purba, A., S.P. Ginting, Z. Poeloengan, K.Simanihuruk Dan Junjungan. 1997. NilaiNutrisi dan Manfaat Pelepah Kelapa Sawits ebagai Pakan Ternak. J. Penelitian KelapaSawit. 5(3): $161-170$.

Sapienza, D.A. and K.K. Bolsen. 1993. Disitasi oleh Bani Nugraha, Penanaman, Pembuatan dan Pemberiannya pada Ternak. Kansas: pione Seed.

Sony, 2012. Material Safty Data Sheet (msds). Banyumas Raya. Purwokerto.

Sutardi, T., Erika B. Lakoni, Idat G. Permana Dan Despal A.B. Tanjung. 1996. Potensi Limbah Perkebunan sebagai Bahan Baku Pakan Ternak. Paper disampaikan pada Pertemuan Tingkat Nasional: Penggalian Sumberdaya Perkebunan untuk Usaha Peternakan, Medan, 11 - 13 Nopember 1996. Loka Penelitian Kambing Potong, PO Box 1 Sungei Putih, Galang 20585.

Sutardi, T. 1980. Landasan Ilmu Nutrisi I. Departemen Ilmu Makanan Ternak, Fakultas Peternakan, Institut Pertanian Bogor, Bogor.

Suwandyastuti, 1991. Nutrisi Pakan Ternak Ruminansia. UI Press. Jakarta.

Tillman, A. D., H. Hartadi., S. Reksohadiprodjo., S. Prawirokusumo dan S. Lebdosoekojo. 1998. Ilmu Makanan Ternak Dasar. Gadjah Mada University Press. Yogyakarta. 